\title{
Development and Validation of UV-Spectroscopic Method for Estimation of Niacin in Bulk and Pharmaceutical Dosage Form
}

\author{
Indranil Chanda ${ }^{1}$, Ripunjoy Bordoloi ${ }^{2}$, Debarupa D. Chakraborty ${ }^{3}$, Prithviraj Chakraborty ${ }^{2}$, Smriti Rekha Chanda Das ${ }^{1}$ \\ ${ }^{1}$ Girijananda Chowdhury Institute of Pharmaceutical Science, Hathkhowapara, Azara, Guwahati-781017, Assam, India. \\ ${ }^{2}$ Bengal College of Pharmaceutical Sciences and Research, B.R.B. Sarani, Bidhannagar, Durgapur-713212, West Bengal, India.
}

\begin{tabular}{l}
\hline ARTICLE INFO \\
\hline Article history: \\
Received on: 01/12/2016 \\
Accepted on: 07/02/2017 \\
Available online: 30/09/2017 \\
\hline Key words: \\
Niacin, UV \\
Spectrophotometric, Method \\
development, validation, ICH \\
guideline.
\end{tabular}

guideline.

\begin{abstract}
A novel, simple, specific and economic UV Spectrophotometric method has been developed using ethanol as solvent to estimate niacin content in bulk and pharmaceutical dosage formulation. The $\lambda_{\max }$ of niacin was found to be $262 \mathrm{~nm}$. Linearity in the concentration range of $01-19 \mu \mathrm{g} / \mathrm{ml}$ was found to be exhibiting good correlation coefficient $\left(\mathrm{R}^{2}=0.9991\right)$. The developed method was validated statistically to demonstrate linearity, accuracy, precision, LOD and LOQ. The validation parameters were selected as per the ICH [Q2 (R1)] guideline. The results of the study proved the applicability of the present method in routine analysis of niacin in bulk as well as in the formulation.
\end{abstract}

\section{INTRODUCTION}

Niacin, known as Vitamin B3 or nicotinic acid, is chemically pyridine-3-carboxylic acid (Fig. 1) official in IP (Indian Pharmacopoeia, 2007); which is a colorless, watersoluble solid. It has the ability to reduce low density lipoprotein cholesterol (LDL), very low-density lipoprotein cholesterol (VLDLC), and triglycerides (TG), and also effectively increase high density lipoprotein cholesterol (HDL) (Villines et al, 2012). Literature survey had revealed various analytical methods (RPHPLC, HPTLC, UV-Spectroscopy, LC-MS/MS (Vasanthi et al, 2015; Narayankar et al, 2015; Pravish and Padmakar, 2010; Ranganath and Raja, 2014; Bratati et al, 2014; Dewani1 et al, 2015) for determination of Niacin in pharmaceutical formulations in combination with other drugs. In the present study, efforts were made in developing a simple, specific and economic

\footnotetext{
* Corresponding Author

Ripunjoy Bordoloi, Research Scholar, Girijananda Chowdhury Institute of Pharmaceutical Science, Hathkhowapara, Azara, Guwahati-781017, Assam, India.Email: ripun.bordoloi @ gmail.com
}

UV spectrophotometric method using ethanol as solvent to determine Niacin content in bulk and pharmaceutical dosage formulation and validate it as per the ICH guidelines (ICH, 2005).<smiles>O=C(O)c1cccnc1</smiles>

\section{NIACIN}

Fig 1: Chemical Structure of Niacin hydro-2H-pyran-2-yl] ethyl \}-3, 7dimethyl-1, 2, 3, 7, 8, 8a-hexahydronaphthalen-1-yl 2, 2-dimethylbutanoate

\section{MATERIALS AND METHODS}

\section{Instruments}

UV-Visible double beam spectrophotometer (UV-1800, Shimadzu, Japan) with $1 \mathrm{~cm}$ matched quartz cells, Micropipette of variable volumes (Microlit, India) and Digital balance (Denver Instrument, Germany) were used. 


\section{Materials}

Niacin API was procured from B. S. Trading, Howrah, West Bengal, having $99.98 \%$ w/w assay value and was therefore used without further purification. Analytical grade Methanol, Potassium dihydrogen phosphate, Hydrochloric acid, Sodium hydroxides were purchased from $\mathrm{CDH}(\mathrm{P})$ Ltd. New Delhi. Niacin tablets were purchased from local pharmacy shop of Guwahati, Assam.

\section{Determination of wavelength of maximum absorption $\left(\lambda_{\max }\right)$}

A standard stock solution of Niacin $(100 \mu \mathrm{g} / \mathrm{ml})$ was prepared using ethanol as solvent and $0.2 \mathrm{ml}$ was diluted to $10 \mathrm{ml}$ with the same solvent to obtain $2 \mu \mathrm{g} / \mathrm{ml}$ reference solutions. The reference solution was scanned in the wavelength region of 200$400 \mathrm{~nm}$.

\section{Linearity and range}

Nineteen solutions (1-19 $\mu \mathrm{g} / \mathrm{ml})$ of different concentration were prepared from the standard stock solution of Niacin for linearity study. The absorbance of these solutions was observed against ethanol as blank at $262 \mathrm{~nm}$ and the obtained data was used for the linearity calibration curve.

\section{LOD and LOQ}

Limit of detection (LOD) and Limit of quantitation (LOQ) for the assay was calculated using the following formula: $\mathrm{LOD}=3.3 \times$ (standard deviation of $y$-intercept of the regression line / slope of the calibration curve)

LOQ $=10 \times$ (standard deviation of $y$-intercept of the regression line / slope of the calibration curve)

\section{Assay of content of Niacin in tablet dosage form}

The newly developed method was applied in order to analyze the Niacin in marketed tablet formulation. Niacin tablet powder equivalent to $100 \mathrm{mg}$ of Niacin was dissolved into $100 \mathrm{ml}$ ethanol by shaking to get the final concentration of $1 \mathrm{mg} / \mathrm{ml}$. The solution was then filtered through Whattman filter paper \#41.This filtrate was diluted suitably with ethanol to get the solution concentration of $10 \mu \mathrm{g} / \mathrm{ml}$. The absorbance of this solution was measured and amount of Niacin was calculated from the calibration curve.

\section{Accuracy}

Accuracy of the developed method was carried out by performing recovery study using standard addition method, in which standard drug was added at three different concentration $(80 \%, 100 \%$ and subsequently by $120 \%)$ to the pre-analyzed formulation $(10 \mu \mathrm{g} / \mathrm{ml})$.

\section{Precision}

Precision study of the method was performed by intraday and inter-day variation study. The intraday precision and interday precision was ascertained by determining absorbance of 3 replicates of a fixed concentration of the drug $(10 \mu \mathrm{g} / \mathrm{ml})$ at three different time period of the same day and on three different days. The result of the precision studies was expressed in terms of $\%$ RSD (percentage of Relative Standard Deviation).

\section{Solution Stability Study}

To test the short term stability of Niacin solution, three different concentrations (2, 4 and $6 \mu \mathrm{g} / \mathrm{ml})$ was prepared and analyzed at 10 hours.

\section{Ruggedness and Robustness}

Ruggedness of the method was determined on carrying out the method by two different analysts and Robustness of the method was determined by measuring the absorbance of $10 \mu \mathrm{g} / \mathrm{ml}$ solution of Niacin at $260 \mathrm{~nm}, 262 \mathrm{~nm}$ and $264 \mathrm{~nm}$.

\section{RESULTS AND DISCUSSION}

\section{Method Development}

The $\lambda_{\max }$ of Niacin in ethanol was found to be $262 \mathrm{~nm}$. Niacin was found to be linear within the concentration range 01-19 $\mu \mathrm{g} / \mathrm{ml}$ and exhibited correlation coefficient of 0.9991 (Fig. 2). The result of regression analysis is given in Table 1.

Table 1: Result of regression analysis of Niacin.

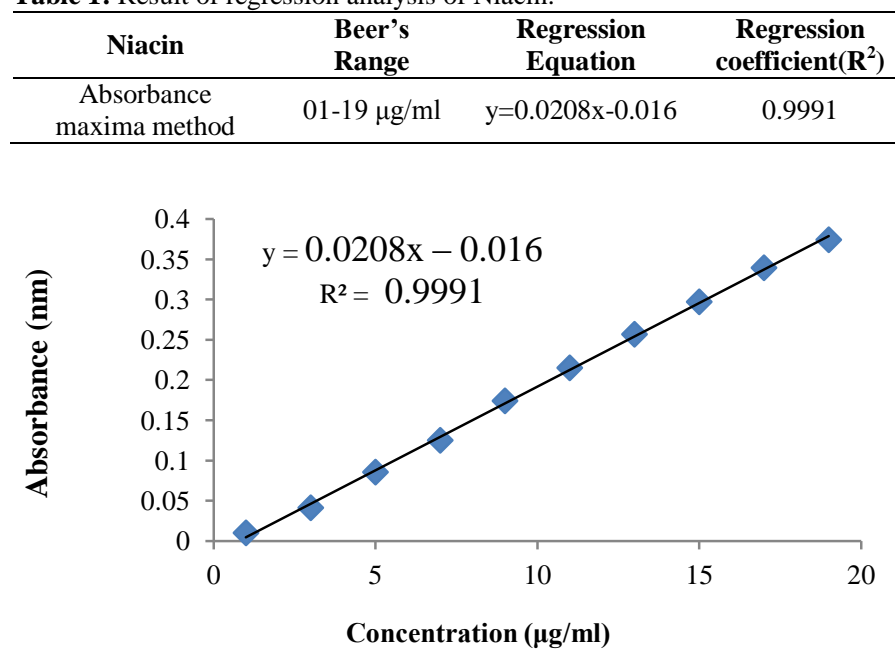

Fig 2: Linearity curve of Niacin at $262 \mathrm{~nm}$.

Validation

LOD and LOQ

The limit of detection (LOD) and limit of quantification (LOQ) were found to be $0.64 \mu \mathrm{g} / \mathrm{ml}$ and $1.94 \mu \mathrm{g} / \mathrm{ml}$ respectively (Table 2) which indicates that the proposed UV method is sensitive.

Table 2: Result of LOD and LOQ.

\begin{tabular}{ccc}
\hline Drug & LOD $(\mu \mathrm{g} / \mathbf{m l})$ & LOQ $(\mu \mathrm{g} / \mathbf{m l})$ \\
\hline Niacin & 0.64 & 1.94 \\
\hline
\end{tabular}

\section{Assay of content of niacin in tablet dosage form}

The assay results of the commercial formulations are shown in (Table 3). The developed method was in good agreement with the label claim. 
Table 3: Result of table assay $(n=3)$.

\begin{tabular}{cccc}
\hline Drug & $\begin{array}{c}\text { Label } \\
\text { Claim }\end{array}$ & $\begin{array}{c}\text { Amount of Drug } \\
\text { estimated (mg/tab) }\end{array}$ & Assay \\
\hline Niacin & $500 \mathrm{mg}$ & $495.97 \pm 0.4645$ & $99.326 \pm 0.1929$ \\
\hline
\end{tabular}

\section{Accuracy}

Results of recovery study were within the range of 99.15$99.66 \%$ indicating that the developed method is an accurate method for determination of niacin. The results are summarized in Table 4.

Table 4: Statistical analysis for ACCURACY of the proposed method.

\begin{tabular}{ccccc}
\hline Sample & \multicolumn{2}{c}{$\begin{array}{c}\text { Concentration } \\
(\boldsymbol{\mu g} / \mathbf{m l})\end{array}$} & \multirow{2}{*}{ \% Recovery } & $\begin{array}{c}\text { Statistical } \\
\text { analysis }\end{array}$ \\
\cline { 2 - 3 } & Pure & Formulation & & \\
\hline S1 80\% & 8 & 10 & 99.65 & Mean : 99.66 \\
S1 80\% & 8 & 10 & 99.54 & SD : 0.0981 \\
S1 80\% & 8 & 10 & 99.78 & \%RSD 0.0984 \\
\hline S2 100\% & 10 & 10 & 99.54 & Mean : 99.15 \\
S2 100\% & 10 & 10 & 98.12 & SD : 0.7354 \\
S2 100\% & 10 & 10 & 99.79 & \%RD 0.7417 \\
\hline S3 120\% & 12 & 10 & 99.43 & Mean : 99.28 \\
S3 120\% & 12 & 10 & 98.59 & SD : 0.5167 \\
S3 120\% & 12 & 10 & 99.83 & \%RSD 0.5204 \\
\hline
\end{tabular}

Table 5: Statistical analysis for INTRADAY ASSAY of the proposed method.

\begin{tabular}{llllll}
\hline Sl. & Concentration & \multicolumn{2}{l}{ Absorbance } & Average \\
\cline { 3 - 5 } No & $(\boldsymbol{\mu g} / \mathbf{m l})$ & Morning & Afternoon & Evening & RSD \\
\hline 1 & 10 & 0.190 & 0.190 & 0.191 & \\
2 & 10 & 0.190 & 0.191 & 0.192 & 0.3677 \\
3 & 10 & 0.191 & 0.189 & 0.190 & \\
$\%$ & RSD & 0.2632 & 0.4211 & 0.4188 & \\
\hline
\end{tabular}

Table 6: Statistical analysis for INTERDAY ASSAY of the proposed method

\begin{tabular}{llllll}
\hline Sl. & Concentration & \multicolumn{2}{l}{ Absorbance } & $\begin{array}{l}\text { Average } \\
\text { \% RSD }\end{array}$ \\
\cline { 2 - 5 } No & $(\boldsymbol{\mu} \mathbf{g} / \mathbf{m l})$ & Day1 & Day2 & Day3 & \\
\hline 1 & 10 & 0.191 & 0.189 & 0.191 & \\
2 & 10 & 0.190 & 0.190 & 0.191 & 0.3672 \\
3 & 10 & 0.192 & 0.191 & 0.190 & \\
$\%$ RSD & 0.4188 & 0.4211 & 0.2618 & \\
\hline
\end{tabular}

\section{Precision}

The developed method was found to be precised as the average \% RSD values for intraday and inter-day precision study was found to be $0.3677 \%$ and $0.3672 \%$ respectively (Table 5 and Table 6)

\section{Solution Stability Study}

Result of short term stability study (Table 7) indicates towards the sample stability in solution for 10 hours which is within the acceptable range.

Table 7: Short term stability study.

\begin{tabular}{cc}
\hline $\begin{array}{c}\text { Concentration } \\
(\mu g / m l)\end{array}$ & $\begin{array}{c}\text { Concentration found } \\
(\text { at } 10 \text { hours }) \\
\text { Mean } \pm \mathrm{SD},(\mu g / m l)\end{array}$ \\
\hline 2 & $1.973 \pm 0.0068$ \\
4 & $\mathbf{3 . 8 7 0} \pm 0.0690$ \\
6 & $5.944 \pm 0.0324$ \\
\hline
\end{tabular}

\section{Ruggedness and Robustness}

It was observed (Table 8 and Table 9) that there were no significant changes in the results, which demonstrated that the developed method is rugged and robust.

Table 8: Statistical analysis for RUGGEDNESS of the proposed method.

\begin{tabular}{|c|c|c|c|c|c|c|}
\hline & \multicolumn{3}{|c|}{ Analyst 1} & \multicolumn{3}{|c|}{ Analyst 2} \\
\hline$\stackrel{\sharp}{\sharp}$ & 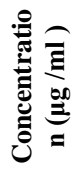 & 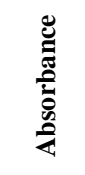 & 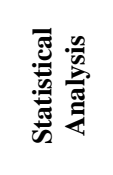 & 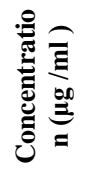 & 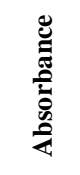 & 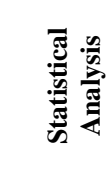 \\
\hline 1 & 10 & 0.191 & ک & 10 & 0.191 & 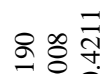 \\
\hline 2 & 10 & 0.192 & $\sum^{\bar{d}} \frac{1}{2} \frac{\hat{n}}{0}$ & 10 & 0.190 & 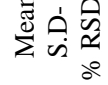 \\
\hline
\end{tabular}

Table 9: Statistical analysis for ROBUSTNESS of the proposed method.

\begin{tabular}{cccc}
\hline Sl. No. & $\mathbf{2 6 0} \mathbf{~ n m}$ & $\mathbf{2 6 2} \mathbf{~ n m}$ & $\mathbf{2 6 4} \mathbf{~ n m}$ \\
\hline 1 & 0.184 & 0.191 & 0.188 \\
2 & 0.186 & 0.192 & 0.187 \\
3 & 0.188 & 0.192 & 0.185 \\
Mean & 0.186 & 0.192 & 0.187 \\
SD & 0.0016 & 0.0005 & 0.0012 \\
\%RD & 0.8602 & 0.2604 & 0.6417 \\
\hline
\end{tabular}

\section{CONCLUSION}

The method proposed in the above study was found to be simple, specific, economic, precise and rapid for the determination of Niacin in bulk as well as in its dosage form. Sample recoveries in all formulations were in good agreement with their respective label claims without interference of excipients and additives. Being economic and precise, the developed method may be preferred as an alternative method for the routine analysis of the Niacin in bulk and pharmaceutical dosage form.

\section{ACKNOWLEDGEMENT}

Authors are thankful to the authority of Girijananda Chowdhury Institute of Pharmaceutical Science, Guwahati for providing necessary facility for conducting this work.

\section{Financial support and sponsorship: Nil.}

Conflict of interest: The authors declare no conflict of interest.

\section{REFERENCES}

Indian Pharmacopoeia. Ghaziabad: The Indian Pharmacopoeia Commission, Govt of India, Ministry of Health and Family Welfare. 2007; 2: 1439 . 
Villines TC, Kim AS, Gore RS, Taylor AJ. Niacin: The evidence, clinical use, and future directions. Curr Atheroscler Rep, 2012; 14(1): 49-59.

Vasanthi R, Prasad J, Alagar Raja M, Prashanthi V, Shrisha V, David Banji, Selva Kumar D. Analytical method development and validation of lovastatin and niacin by using rp-hplc method. Asian J Pharm Anal Med Chemm 2015; 3(3):128-136.

Narayankar Savita M, Sakpal Promod H, Bhingare Chandrashekhar L, Ingale Pramod L. Development and validation of rphplc method for the estimation of rosuvastatin calcium and niacin in combined tablet dosage form. Int J Pharm Res Rev, 2015; 4(6):44-50.

Pravish Kumar Tiwari, Padmakar Sathe. Development and validation of HPTLC method for niacin and simvastatin in binary combination. Adv Biosci Biotechnol, 2010; 1:131-135.

Ranganath MK, Raja Ram Chowdary. Simultaneous estimation and validation of niacin and atorvastatin calcium by uv-spectroscopy in pure and tablet dosage form using methanol: water mixture as solvent. RGUHS J Pharm Sci, 2014; 4 (2):70-77.

Bratati Roy, Bhupinder Singh, Anjana Rizal CP Malik. Bioanalytical method development and validation of niacin and nicotinuric acid in human plasma by LC-MS/MS. Int J Pharm Clin Res, 2014; 6(3): 206-213.

Dewani1 AP, Mohale DS, Hiware S, Bakal RL, Chandewar AV, Mohd Salimuddin Farooqui. Development and validation of rp-hplc method for simultaneous estimation of niacin and simvastatin in tablet dosage. Indian J Pharm Pharmacol, 2015; 2(1): 21-26.

Validation of analytical procedures: text and methodology, in: International Conference on Harmonization (ICH), Q2(R1), IFPMA, Geneva, Switzerland, 2005.

\section{How to cite this article:}

Chanda I, Bordoloi R, Chakraborty DD, Chakraborty P, Das SR. Development and Validation of Uv-Spectroscopic Method for Estimation of Niacin in Bulk and Pharmaceutical Dosage Form. J App Pharm Sci, 2017; 7 (09): 081-084. 